\title{
Ruptured Primary Ovarian Pregnancy: A Rare Case Report
}

\section{Shrestha $A,{ }^{1}$ Chawla CD, ${ }^{1}$ Shrestha $\mathrm{RM}^{2}$}

\author{
${ }^{1}$ Department of Obstetrics and gynecology \\ ${ }^{2}$ Department of Pathology \\ Kathmandu University Hospital, Dhulikhel Hospital \\ Kavre, Nepal \\ Corresponding Author \\ Abha Shrestha \\ Department of Obstetrics and gynecology, \\ Kathmandu University Hospital, Dhulikhel Hospital \\ Kavre, Nepal \\ E-mail: phuche_001@yahoo.com
}

\begin{abstract}
Ovarian pregnancy is an uncommon presentation of ectopic gestation and usually, it ends with rupture before the end of the first trimester. Its presentation often is difficult to distinguish from that of tubal ectopic pregnancy and hemorrhagic ovarian cyst. We report a rare primary ruptured ovarian pregnancy in a 26 years lady.
\end{abstract}

\section{KEYWORDS}

First trimester, hemorrhagic ovarian cyst, ovarian pregnancy

\section{Citation}

Shrestha A, Chawla CD, Shrestha RM. Ruptured Primary Ovarian Pregnancy: A Rare Case Report. Kathmandu Univ Med J 2012;39(3):76-77.

\section{INTRODUCTION}

Ovarian pregnancy is an uncommon presentation of ectopic gestation as per the criteria described by Speigelberg. ${ }^{1}$ Usually, it ends with rupture, which occurs before the end of the first trimester. Its presentation often is difficult to distinguish from that of tubal ectopic pregnancy and hemorrhagic ovarian cyst. The prevalence is up to approximately $1-3 \%$ of all extrauterine pregnancies. ${ }^{2}$

\section{CASE REPORT}

A 26 years old patient with nine weeks amenorrhoea presented to the emergency department of Kathmandu University Hospital, Dhulikhel on $20^{\text {th }}$ July 2010 with history of severe sudden onset lower abdominal pain for one day and on examination the blood pressure was $90 / 60 \mathrm{~mm}$ of $\mathrm{Hg}$ and her pulse pressure was 110/minute. She was pale. Examination of abdomen reveals tenderness and rigidity. There was no vaginal bleeding whereas cervical excitation was there. The investigation showed positive urine hCG test. Transvaginal sonography revealed the gestational sac in the right ovary of the MSD (mean sac diameter) of $15 \mathrm{~mm}$ corresponding to the sixth gestational week. Free fluid was also noted in the Douglas pouch. The Culdocentesis was positive for hemoperitoneum. So the diagnosis was made as ruptured ectopic pregnancy. Henceforth, emergency laparotomy was performed and found to be ruptured right ovarian pregnancy as shown in fig 1 . So, wedge resection of the ovary was performed and sent for the histopathological examination.

Histopathological examination showed ovarian parenchyma containing blood clots with both trophoblastic tissues and chorionic villi consistent with ovarian ectopic pregnancy as shown in fig 2 and 3.

The patient had uneventful postoperative period and was discharged without complications.

\section{DISCUSSION}

Ovarian pregnancy is defined as those primarily of ovarian 


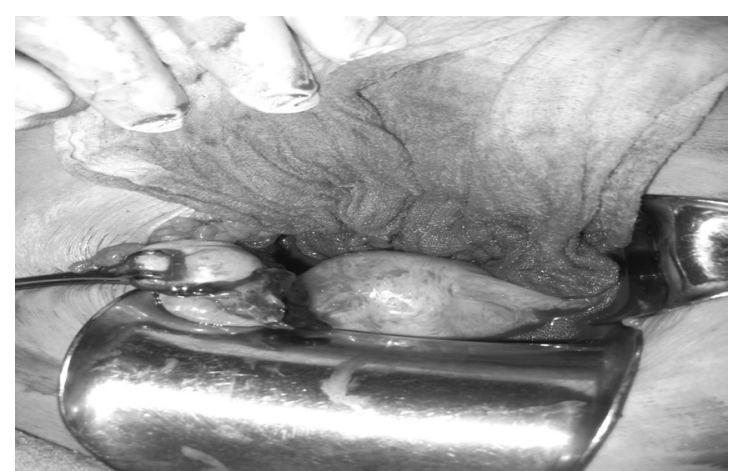

Fig1. Showing ruptured right sided ectopic pregnancy.

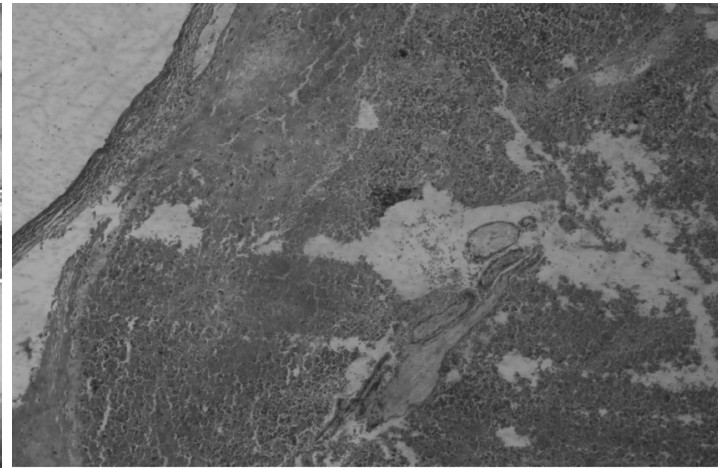

Fig 2. Showing ovarian parenchyma containing blood clots with both trophoblastic tissues and chorionic villi.

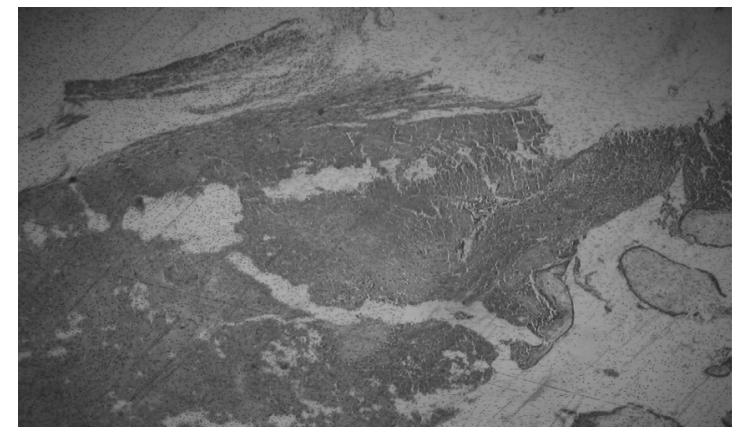

Fig 3. Also showing ovarian parenchyma containing blood clots with both trophoblastic tissues and chorionic villi.

origin. There may also be chance of involvement of ovary following tubal abortion. The first reported case in the literature was from Saint Maurice of France in $1682 .^{3}$ This primary ovarian pregnancy is regarded as rare case in medical literature but somehow nowadays it seems to be more frequent because of the use of intrauterine contraceptive devices. ${ }^{4}$

Spiegelberg had set certain criteria for diagnosing primary ovarian pregnancy. They are 1) the tube on the affected site must be distinctly separated from ovary and intact. 2) The gestational sac definitely occupies normal side of ovary. 3) The sac must connect with uterus by ovarian ligament .4) There must be unquestionable ovarian tissue in the wall of sac. Basically, these ovarian pregnancies are confused with corpus luteal cyst, hemorrhagic corpus luteum and also with ruptured endometriotic cyst. So, the confirmation is done by histopathological examination. ${ }^{5}$

As reported cases in literature are most of that of young age group like in our case. So, the one of the treatment option is that of the wedge resection of ovary like we did in our case. ${ }^{6,7}$ There are also medical means of management like using of methotrexate but may not be feasible. So, it is taken as the option if there is persistent trophoblastic tissues even after laparoscopy. ${ }^{8}$

The location of ovarian pregnancy could be different as per described by Botella and they are either superficial, within the corpus luteum or in the stroma. ${ }^{4}$ There are various postulations available in literature regarding the primary ovarian pregnancy. They could be obstructed ovulation, malfunction tube from previous salpingitis, favourable surface phenomenon because of decidual reaction or endometriosis, use of intrauterine device and also likelihood of chance occurrence. ${ }^{6,9}$

Since, in our case we could not find the exact and apparent cause for the ovarian pregnancy. So, there is high probability of chance occurrence.

\section{REFERENCES}

1. Gerin-Lajoie L. Ovarian pregnancy. Am J Obstet Gynecol 1951;62:9209.

2. Te Linde RW. Ginecología Operatoria. 5ta ed. Editorial CientíficoTécnica 1983; 326.

3. Farell DM, Abrams J. Primary ovarian pregnancy; report of a case. Med J Malaysia 1957;42:70-1.

4. Botella J, Clavero JA. Tratado de Ginecología. 12ma ed. T II. Editorial Científico-Técnica 1983; 401.

5. Tan KK, Yeo OH. Primary ovarian pregnancy. Am J Obstet Gynecol 1968;100:240-9.

6. Boronow RC, McElin TW, West RH, Buckingham JC. Ovarian pregnancy; report of four cases and a thirteen years survey of the English literature. Am J Obstet Gynecol 1965;91:1095-108.

7. Seinera P, DiGregorio A, Arisio R, Decko A, Crana F. Ovarian pregnancy and operative laparoscopy: report of eight cases. Hum Reprod 1997; 12(3): 608-610.

8. Einenkel J, Baier D, Horn L-C, Alexander H. Laparoscopic therapy of an intact primary ovarian pregnancy with ovarian hyperstimulation syndrome. Hum Reprod 2000; 15(9): 2037-2040.

9. Ringachary D, Fayez JA, Jonas HS. Ovarian pregnancy. Obstet Gynecol (Suppl) 1977;4976s-8s. 